\title{
Factors Affecting Color of Cut Pile Carpets
}

\author{
Ikuko Hirai* and Toshihiro Gunji**
}

\begin{abstract}
In the color matching of cut pile carpets, a prediction of the color of carpets is made from the color of crosssectional and longitudinal surfaces of yarns constituting a carpet. Generally, it is know that the color of a cross -sectional surface of yarns is deeper than that of a longitudinal surface of yarns. A "pompon" of the color sample of cut pile carpets was used as a sample.

Firstly, a color difference between the cross-sectional and longitudinal surface of yarns was measured with a spectrophotometric colorimeter. It has been found that the color of carpets were very susceptible to illuminance.

Secondly, a procedure was discussed to predict the color perceived with eyes. A color of cross-sectional surface of a "pompon" was measured with a non-contact photoelectric colorimeter by varying a degree of surface illuminance of a sample. It was found that the visual color of cross-sectional surface of a "pompon" agreed with the $Y$ value of illuminance of longitudinal surface of yarns, when a surface illuminance of a sample was $7501 x$.

Finally, the variation of illuminance in a "pompon" was measured with an illumination sensor inserted into a "pompon". In order to examine the illuminance inside carpets, a comparison of measured value inside carpets to an illuminance calculated by a "pompon model" was made by changing the position of a sensor. When the angle of incidence was equal to zero degree, the light entered more deeply into the "pompon". The degree of illuminance decreased about $50 \%$ at $5 \mathrm{~mm}$ down and about $90 \%$ at $10 \mathrm{~mm}$ down from the surface of a "pompon".
\end{abstract}

Key Words : Cut Pile Carpt, Color Measurement, Pompon, Color Matching, Illuminance

(Received Dec. 4, 1997)

(Accepted for Publication May 11, 1999)

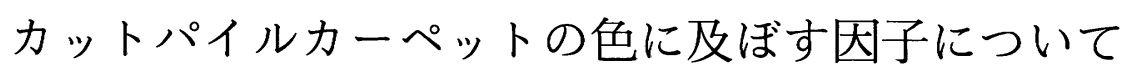

平井 郁子*, 軍司 敏博**

\section{1。緒，言}

従来, カットパイルカーペットの色だしは, 経験 的に糸側面集合体の色と糸断面集合体の色加，力 一ペットの色を予測して行われている. 一般にカー ペットの糸断面集合体の色は，系側面集合体の色よ りあ濃色になるといわれている1． そこで，糸側面 集合体の色と糸断面集合体の色に生じる色差の不便 さをなくしたカーペットの色だし方法を得ることを 目的に実験を行った.

まず，糸側面集合体の色と糸断面集合体の色の間 には, どのくらいの色差が生じているかを, カット
パイルカーペットの色見本のボンテンを試料として 多光源分光測色計を用いて測色した:

次に視覚で見るカーペットの色に最も近い色を予 測するために，実際にカーペットを見る場合を想定 して, ボンテンの表面照度を変化させ，非接触色彩 色差計を用いて測定を行った。

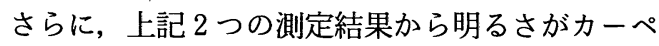
ットの色に影響すると考えられたため, カーペット 内部の明るさがカーペット表面からの深さにより, どのように変化するのかを，2本のカーペット糸間 を拡大し，モデル化した「ボンテン・モデル」を想 定して照度変化を計算で求めた. また，ボンテン内

*Member, Institute of Human Living Sciences Otsuma Women's University, Chiyoda-ku, Tokyo, 会員 大妻女子大学人間生活 科学研究所, 東京都千代田区三番町, ** Member, Otsuma Women's University, Chiyoda-ku, Tokyo, 会員, 大妻女子大学, 東京 都千代田区三番町 
部に照度センサーを入れ，ボンテン内部の深さによ る照度変化を測定した。この計算値と実測値を比較 検討し，カーペットの色だしに役立つ法則性を見い 出す手掛かりを得ることができないかを検討した.

\section{2. 試料および実験方法}

\section{1 試 料}

試料として, 日本建築敷物協会試作の色見本・ボ ンテン, ウールカットパイルカーペット用720色を 用いた。

\section{2 実験方法}

\section{（1） 糸側面集合体と糸断面集合体の測色}

スガ試験機製多光源分光測色計 MSC-IS-2B を用 い, 720色のボンテンの糸側面集合体と糸断面集合 体を測色し, $\mathrm{H} ・ \mathrm{~V} / \mathrm{C}, \mathrm{L}^{*}, \mathrm{a}^{*}, \mathrm{~b}^{*}, \triangle \mathrm{L}^{*}, \triangle \mathrm{E}^{*}{ }_{\mathrm{ab}}$ を求めた. 測色条件は $\mathrm{C}$ 光源, $2^{\circ}$ 視野, $\mathrm{d}-0$ 受光で 行った.

この糸側面集合体の測色値の中からマンセル色相 環の主要10色相で, 中央值 5 に近いすのをすべて選 び出し, 系側面集合体と糸断面集合体それぞれにつ いて, 測色値の平均を求めた. また, その色差がグ レースケールの何級に相当するかをみるため JIS L $0805_{1983}$ 污染用グレースケールについても同様に測 色を行い,グレースケール 5 級（白）との差を求め 比較検討した。

\section{（2）試料面照度を変化させた場合の測色}

カーペットを見るときは, カーペットの糸断面だ けでなく, 系と系の陰影等, トータルとしてカーペ ットの色を見ている，そこで，実際に我々がカーペ ットを見る状態を想定しボンテンの測色を行った.

測色条件は, JIS Z 8723 ${ }_{1961}$ の表面比較方法の45度 方向から照明し, 垂直方向から観察する方法を採用 した. また，このときの照度は，JISには明確に規定 されていないためISO/TR9405-1990の1500 1x を参 考にした。

このとき色相および彩度の影響を検討するためボ ンテンは, 720色の中から色の代表として三原色 (R, G, B ) で色相值が 5 に近いもの 3 種類, および ニュートラル色の明度值が 1 (Black), 5 (Gray),

8 (White) に近いもの 3 種類を選び出し使用した. 測色計としては，非接触タイプのミノルタ製色彩 色差計 CS-100を用いた. 測色計の仕様は, 聞き角 : 1 度, 測定距離範囲 : $1000 \mathrm{~mm} \sim \infty$, 最小測定範囲

\section{Spectorophotometric colorimeter}

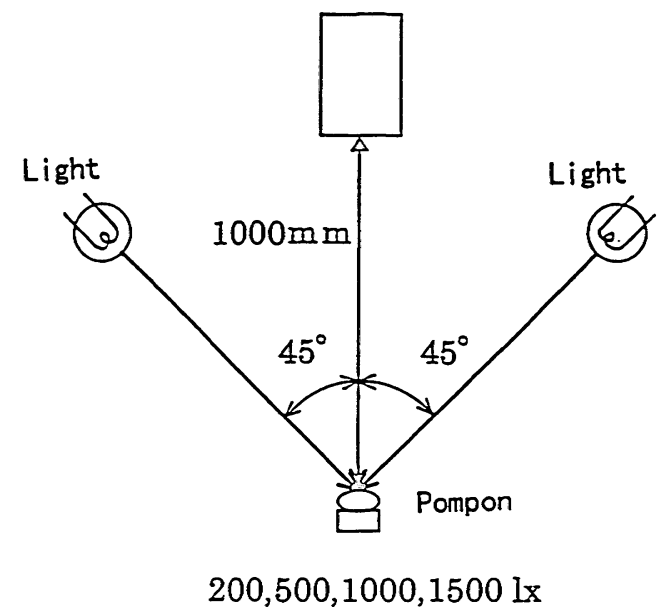

Fig. 1 Method of pompon color measurement

\section{: $14.4 \mathrm{~mm} \phi$ である.}

照度変化をさせたときのボンテン測色方法の概略 を図 1 に示した. 色彩色差計とボンテンからの距離 を $1 \mathrm{~m}$ とし, 照明は左右 2 灯で $45^{\circ}$ 入射 $-0^{\circ}$ 受光と した.

光源は, 岩崎電気製ブルーライト $500 \mathrm{~W}$ を使用し た.このライトの電圧は $80 \mathrm{~V} \sim 100 \mathrm{~V}$ とし, 試料の照 度を $2001 \mathrm{x}, 500 \mathrm{~lx}, 1000 \mathrm{~lx}, 1500 \mathrm{~lx}$, と変化させ測 色を行った. ブルーライト $100 \mathrm{~V}$ のときの色温度は $5900 \mathrm{~K}, 80 \mathrm{~V}$ のときの色温度は $5450 \mathrm{~K}$ で, 白色の範 囲にはいるので色温度による差は問題にならない。

\section{（3） ボンテン内部の照度}

(1)，(2)の実験から明るさがカーペットの色に影響 することがわかった，そこでカーペット内部の明る さがカーペット表面からの深さにより，どのように 変化するかを知ることによって，カーペットの色だ しに役立つ法則性を見出すことができないか，次の ような実験を行った。

まず, 実際にボンテン内部の照度変化を測定し た.このときのボンテンは, 720色の中から代表とし て三原色（R，G，B）で色相の值が各色の中間であ る 5 に近いもの 3 種類およびニュートラル色の明度 值が 1 (Black), 5 (Gray), 8 (White) に近いもの 3 種類を選び出し使用した.

次に 2 本のカーペット糸間を拡大し, モデル化し たあのを「ボンテン・モデル」とし, 光の相互反射 条件につきシミュレーションを行い, ボンテン内部 の照度変化を求めた。

最後に実測値と計算値との比較を試みた。 


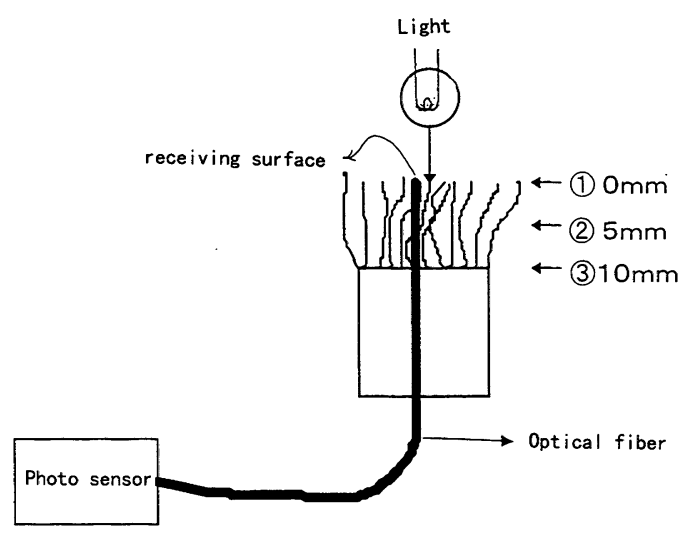

Fig. 2 Illuminance measurement method of inside pompon

図 2 にはボンテン内部の照度測定方法を示した. ボンテン表面を1500 lx の照度にしたとき，ボンテ ン内の照度センサーの深さをボンテン表面から(1)0 $\mathrm{mm}$, (2) $5 \mathrm{~mm}$, (3) $10 \mathrm{~mm}$ と変化させ, ボンテン内の 照度変化を測定した。

測定器は, 試作微小面照度測定ユニット（村上色 彩研究所製）を使用した. 試作微小面照度测定ユニ ットの仕様は, 受光面サイズ : $2.4 \mathrm{~mm} \phi$, 波長範囲 $: 320 \mathrm{~nm} \sim 730 \mathrm{~nm}$, フォトセンサー：浜松フォトニ クス製フォトダイオード S1133である.

\section{3、結果および考察}

\section{1 糸側面集合体と糸断面集合体の測色}

ボンテン 720 色中, R (Red), YR (Yellowish Red), Y (Yellow), GY (Greenish Yellow), G (Green), BG (Blueish Green), B (Blue), PB (Perpleish Blue), P (Perple), RP (Redish Perple）の色相において，各色相の中間である $5 \mathrm{H}$ (4.5 5.5H) に近いボンテンについての H・V/C, $\mathrm{L}^{*}, \mathrm{a}^{*}, \mathrm{~b}^{*}, \Delta \mathrm{L}^{*}, \Delta \mathrm{E}^{*}{ }_{\mathrm{ab}}$ の測色值の平均を表 1 に 示す.ここで $\Delta \mathrm{L}^{*}$ は, 系側面集合体の $\mathrm{L}^{*}$ 值と糸断 面集合体の $\mathrm{L}^{*}$ 值の差である. $\Delta \mathrm{E}^{*}{ }_{\mathrm{ab}}$ は，系側面集 合体と糸断面集合体の色差である.

また, 表 2 は, JIS L 0805污染用グレースケール の測色值および 5 級（白）と各級との明るさの差 $\Delta \mathrm{L}^{*}$, 色差 $\Delta \mathrm{E}^{*}{ }_{\mathrm{ab}}$ の值を求めたものである.

表 1 の測色結果から次のことがわかった.

(1)すべての色のカーペットについて, $\mathrm{L}^{*}$ の值は, 糸 側面集合体よりあ糸断面集合体の值の方が低く, 濃色である. 特に $\mathrm{P}, \mathrm{G}, \mathrm{BG}, \mathrm{PB}$ では, 明るさの 差 $\Delta \mathrm{L}^{*}$ がやや大きな傾向が見られる.

(2)糸側面集合体と糸断面集合体との明るさの差 $\Delta \mathrm{L}^{*}$ と色差 $\Delta \mathrm{E}^{*}{ }_{\mathrm{ab}}$ との間には, 高い相関 $(\mathrm{r}=$ 0.967）が得られた.

(3)彩度 $\mathrm{C}$ と色差 $\Delta \mathrm{E}^{*}{ }_{\mathrm{ab}}$ との間には, 相関 $(\mathrm{r}=$ 0.468）は得られなかった。

(4)カーペットの糸側面集合体と糸断面集合体の明度 差 $\Delta \mathrm{L}^{*}$ の平均值：11.91および色差 $\Delta \mathrm{E}^{*}{ }_{\mathrm{ab}}$ の平 均值：12.78は, JIS L 0805 污染用グレースケー ルの 2-3 級 $\left(\Delta \mathrm{L}^{*}: 12.10, \Delta \mathrm{E}^{*}{ }_{\mathrm{ab}}: 12.34\right)$ に相当 する.

以上のことから，カーペットの糸側面集合体の色

Table 1 Results of color measurement of longitudinal surface and cross-sectional surface of yarns

\begin{tabular}{|c|c|c|c|c|c|c|c|}
\hline Sample & Position & $\mathrm{H} \cdot \mathrm{V} / \mathrm{C}$ & $L *$ & $a *$ & b* & $\Delta L *$ & $\Delta E^{*}{ }_{a b}$ \\
\hline \multirow[t]{2}{*}{$\bar{R}$} & Longitudinal surface & $4.91 \mathrm{R} \cdot 3.15 / 7.92$ & 32.34 & 35.29 & 16.19 & & \\
\hline & Cross sectional surface & $6.89 R \cdot 2.40 / 6.86$ & 24.65 & 31.17 & 14.92 & 7.69 & 8.98 \\
\hline \multirow[t]{2}{*}{$\overline{Y R}$} & Longitudinal surface & $5.05 Y R \cdot 6.18 / 4.10$ & 63.44 & 10.94 & 20.89 & & \\
\hline & Cross sectional surface & $3.75 Y R \cdot 5.02 / 4.84$ & 51.67 & 15.25 & 22.49 & 11.77 & 13.34 \\
\hline \multirow[t]{2}{*}{$\bar{Y}$} & Longitudinal surface & $4.99 Y=6.67 / 2.22$ & 68.22 & -1.81 & 16.62 & & \\
\hline & Cross sectional surface & $4.61 Y \cdot 5.69 / 2.71$ & 66.75 & -1.19 & 19.51 & 9.82 & 11.10 \\
\hline \multirow[t]{2}{*}{ GY } & Longitudinal surface & $5.09 \mathrm{GY} \cdot 5.70 / 3.53$ & 58.65 & -12.38 & 21.89 & & \\
\hline & Cross sectional surface & $5.44 \mathrm{GY}=4.57 / 3.81$ & 47.04 & -13.05 & 21.47 & 11.61 & 12.32 \\
\hline \multirow[t]{2}{*}{$\mathbf{G}$} & Longitudinal surface & $4.94 \mathrm{G} \cdot 4.76 / 3.28$ & 49.03 & -17.31 & 5.91 & & \\
\hline & Cross sectional surface & $5.03 \mathrm{G} \cdot 3.42 / 3.06$ & 35.11 & -15.26 & 4.13 & 13.92 & 14.51 \\
\hline \multirow[t]{2}{*}{ BG } & Longitudinal surface & $4.96 \mathrm{BG} \cdot 4.92 / 2.79$ & 50.74 & -13.55 & -2.14 & & \\
\hline & Cross sectional surface & $5.42 \mathrm{BG} \cdot 3.68 / 2.82$ & 37.85 & -13.05 & -2.84 & 12.89 & 13.24 \\
\hline \multirow[t]{2}{*}{ B } & Longitudinal surface & $5.18 \mathrm{~B} \cdot 4.85 / 2.46$ & 49.93 & -7.02 & -8.07 & & \\
\hline & Cross sectional surface & $5.43 \mathrm{~B} \cdot 3.66 / 2.38$ & 37.66 & -6.37 & -8.29 & 12.27 & 12.69 \\
\hline \multirow[t]{2}{*}{ PB } & Longitudinal surface & $4.95 \mathrm{~PB}=4.93 / 2.70$ & 50.74 & 0.64 & -10.72 & & \\
\hline & Cross sectional surface & $4.98 \mathrm{~PB} \cdot 3.70 / 2.72$ & 38.05 & 0.99 & 11.77 & 12.69 & 13.17 \\
\hline \multirow[t]{2}{*}{$P$} & Longitudinal surface & $5.08 \mathrm{P} \cdot 4.25 / 3.41$ & 43.83 & 11.12 & -11.07 & & \\
\hline & Cross sectional surface & $4.29 \mathrm{P} \cdot 2.90 / 2.90$ & 29.83 & 10.43 & -11.03 & 14.00 & 14.40 \\
\hline \multirow[t]{2}{*}{ RP } & Longitudinal surface & $5.06 \mathrm{RP} \cdot 4.11 / 5.75$ & 42.33 & 26.00 & -3.81 & & \\
\hline & Cross sectional surface & 7.01RP-2.91/4.44 & 29.87 & 21.40 & -1.84 & 12.46 & 14.08 \\
\hline \multirow[t]{2}{*}{ Average } & Longitudinal surface & $4.95 / 3.82$ & 50.93 & & & & \\
\hline & Cross sectional surface & $3.80 / 3.65$ & 39.85 & & & 11.91 & 12.78 \\
\hline
\end{tabular}


Table 2 Results of color measurement of Gray Scale for assessing staining

\begin{tabular}{|l|c|c|c|c|c|c|}
\hline Grade & $\mathrm{H} \cdot \mathrm{V} / \mathrm{C}$ & $\mathrm{L}^{*}$ & $\Delta \mathrm{L}^{*}$ & $\mathrm{a}^{*}$ & $\mathrm{~b}^{*}$ & $\Delta \mathrm{E}{ }^{*} \mathrm{ab}$ \\
\hline 5 White & $7.25 \mathrm{Y} \cdot 9.22 / 0.34$ & 93.27 & - & -0.75 & 2.98 & - \\
\hline $4-5$ & $9.43 \mathrm{Y} \cdot 9.02 / 0.27$ & 91.29 & 1.98 & -0.75 & 2.38 & 2.07 \\
\hline 4 & $9.36 \mathrm{Y} \cdot 8.82 / 0.25$ & 89.35 & 3.92 & -0.68 & 2.17 & 4.00 \\
\hline $3-4$ & $3.72 \mathrm{GY} \cdot 8.60 / 0.19$ & 87.15 & 6.12 & -0.77 & 1.59 & 6.28 \\
\hline 3 & $5.92 \mathrm{GY} \cdot 8.37 / 0.16$ & 84.92 & 8.35 & -0.76 & 1.16 & 8.55 \\
\hline $2-3$ & $1.24 \mathrm{G} \cdot 7.98 / 0.14$ & 81.17 & 12.10 & -0.85 & 0.58 & 12.34 \\
\hline 2 & $1.86 \mathrm{BG} \cdot 7.44 / 0.15$ & 75.91 & 17.36 & -0.90 & 0.08 & 17.60 \\
\hline $1-2$ & $1.78 \mathrm{~B} \cdot 6.68 / 0.22$ & 68.46 & 24.81 & -0.84 & -0.48 & 25.05 \\
\hline 1 & $8.05 \mathrm{~B} \cdot 5.62 / 0.34$ & 57.84 & 35.43 & -0.73 & -1.10 & 35.66 \\
\hline
\end{tabular}

と糸断面集合体の色の差は, 彩度よりも, 明るさが 大きくかかわっていることがわかる.

これは, 糸断面集合体の測色値が，糸の断面のみ でなく, 糸と糸との陰影および糸の光吸収が明るさ に影響しているものと考えられる. また，色差は， JIS L 0805の污染用グレースケールの 2-3 級に相等 する.このことから糸側面集合体の測色値と糸断面 集合体の測色値には, 明るさに差があることが理解 できる.

\section{2 試料面照度を変化させた場合の測色}

ボンテン（三原色：3 種, ニュートラル色 : 3 種） の糸側面集合体と糸断面集合体の測色値を表 3 に示 し, 照度を变化させた場合の測色結果を表 4 に示 す. 3.1 糸側面集合体と糸断面集合体の測色の実験 結果および考察から, カーペットの色に明るさが大 きく影響していることがわかった，そこで，照度変 化とボンテンの明るさ $\mathrm{Y}$ 值との関係をグラフにし たものを図 3 に示す. 図 3 から照度を $2001 \mathrm{~lx} \sim 1500$ $1 \mathrm{x}$ まで変化させた場合, 照度を下げるとボンテンの
$\mathrm{Y}$ 值す比例して低下することがわかった。

また，ボンテンの糸側面集合体の明るさ $\mathrm{Y}$ 值と, 照度7501x で非接触でボンテンの真上から測色した ときの明るさ $\mathrm{Y}$ 值とを比較した結果を表 5 に示す. 糸側面集合体の明るさ $\mathrm{Y}$ 值は, ボンテンの照度を, $500 \mathrm{~lx}$ と $1000 \mathrm{~lx}$ の中間の750 lx にして, 非接触で 測色したときの明るさ $\mathrm{Y}$ 值に相当することがわか る.

この結果から，ボンテンの表面照度を約750 lx に して, 真上から見たときのボンテンの色は, ボンテ

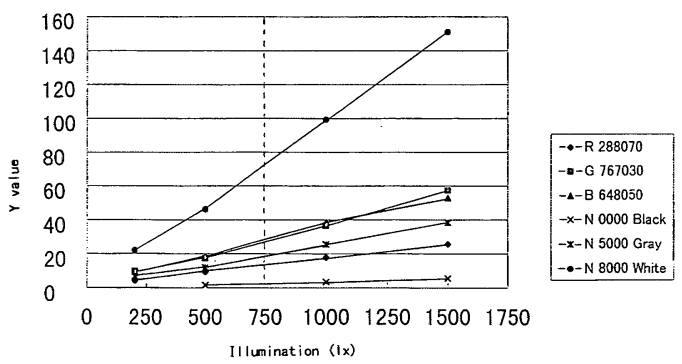

Fig. 3 Relationship between surface illuminance of pompon and $\mathrm{Y}$ value

Table 3 Results of color measurement of pompon

(Three primary colors and achromatic colors)

\begin{tabular}{|c|c|c|c|c|c|c|c|}
\hline Sample & Position & $H \cdot V / C$ & $\bar{x}$ & $\bar{Y}$ & $\bar{z}$ & $x$ & $y$ \\
\hline \multirow[t]{2}{*}{ R 288070} & Longitudinal surface & $5.03 R \cdot 3.95 / 10.64$ & 19.16 & 11.68 & 6.17 & 0.5178 & 0.3157 \\
\hline & Cross sectional surface & $6.84 R \cdot 2.94 / 9.34$ & 10.90 & 6.29 & 2.53 & 0.5529 & 0.3188 \\
\hline \multirow[t]{2}{*}{ G 767030} & Longitudinal surface & 6.26 G. $5.71 / 2.38$ & 23.16 & 26.79 & 28.74 & 0.2943 & 0.3404 \\
\hline & Cross sectional surface & $8.50 G \cdot 4.23 / 2.95$ & 11.10 & 13.60 & 14.80 & 0.2810 & 0.3442 \\
\hline \multirow[t]{2}{*}{ B 648050} & Longitudinal surface & $5.02 B \cdot 5.52 / 4.24$ & 21.54 & 24.84 & 39.51 & 0.2508 & 0.2892 \\
\hline & Cross sectional surface & $5.30 \mathrm{~B} \cdot 4.04 / 4.59$ & 10.32 & 12.27 & 22.61 & 0.2283 & 0.2715 \\
\hline N 0000 & Longitudinal surface & $4.74 \mathrm{RP} \cdot 1.71 / 0.19$ & 2.44 & 2.44 & 2.93 & 0.3125 & 0.3126 \\
\hline Black & Gross sectional surface & $4.05 Y \cdot 1.05 / 0.03$ & 1.25 & 1.28 & 1.49 & 0.3117 & 0.3178 \\
\hline N 5000 & Longitudinal surface & $1.14 \mathrm{P} \cdot 4.87 / 0.29$ & 18.40 & 18.65 & 22.63 & 0.3085 & 0.3125 \\
\hline Gray & Cross sectional surface & $8.45 \mathrm{~PB} \cdot 3.59 / 0.45$ & 9.40 & 9.49 & 11.98 & 0.3045 & 0.3075 \\
\hline N 8000 & Longitudinal surface & $9.21 Y \cdot 7.21 / 0.44$ & 44.82 & 46.10 & 50.81 & 0.3162 & 0.3252 \\
\hline White & Cross sectional surface & $8.56 \mathrm{Y} \cdot 6.20 / 0.54$ & 31.51 & 32.46 & 34.98 & 0.3185 & 0.3280 \\
\hline
\end{tabular}


Table 4 Results of color measurement of pompon as a function of illuminance

\begin{tabular}{|c|c|c|c|c|c|c|c|}
\hline Sample & Illuminance & $\mathrm{H} \cdot \mathrm{V} / \mathrm{C}$ & $\mathrm{x}$ & $\mathbf{Y}$ & $z$ & $\mathbf{x}$ & $y$ \\
\hline \multirow[t]{4}{*}{ R 288070} & $1500 \mathrm{Ix}$ & $4.51 R \cdot 5.61 / 19.29$ & 49.11 & 25.70 & 10.01 & 0.579 & 0.303 \\
\hline & $10001 x$ & $5.63 R \cdot 4.79 / 16.79$ & 33.90 & 17.90 & 5.76 & 0.589 & 0.311 \\
\hline & $5001 x$ & $8.25 R \cdot 3.56 / 12.47$ & 16.78 & 9.32 & 2.06 & 0.596 & 0.331 \\
\hline & $2001 x$ & $5.94 R \cdot 2,35 / 9.48$ & 7.88 & 4.13 & 2.19 & 0.555 & 0.291 \\
\hline \multirow[t]{4}{*}{ G 767030} & $1500 \mathrm{Ix}$ & $1.51 \mathrm{G} \cdot 7.90 / 1.95$ & 51.60 & 57.30 & 58.64 & 0.308 & 0.342 \\
\hline & $10001 x$ & $0.25 \mathrm{~PB} \cdot 6.52 / 4.72$ & 33.76 & 36.50 & 60.09 & 0.259 & 0.280 \\
\hline & $500 \mathrm{Ix}$ & $3.39 \mathrm{BG} \cdot 4.73 / 2.05$ & 15.26 & 17.40 & 20.88 & 0.285 & 0.325 \\
\hline & $2001 x$ & $2.10 \mathrm{~PB} \cdot 3.57 / 3.78$ & 8.97 & 9.70 & 18.23 & 0.295 & 0.322 \\
\hline \multirow[t]{4}{*}{ B 648050} & $1500 / x$ & $2.40 \mathrm{~PB} \cdot 7.64 / 7.04$ & 49.75 & 53.00 & 100.31 & 0.245 & 0.261 \\
\hline & $1000 / x$ & $8.24 \mathrm{GY} \cdot 6.67 / 2.05$ & 34.58 & 38.40 & 36.11 & 0.317 & 0.352 \\
\hline & $500 \mathrm{Ix}$ & $4.12 G Y=4.83 / 3.02$ & 16.14 & 18.30 & 12.61 & 0.343 & 0.389 \\
\hline & $2001 x$ & $2.10 \mathrm{~PB} \cdot 3.57 / 3.78$ & 8.97 & 9.41 & 18.23 & 0.245 & 0.257 \\
\hline \multirow{4}{*}{$\begin{array}{l}\text { N } 0000 \\
\text { Black }\end{array}$} & $1500 \mathrm{Ix}$ & $2.62 R \cdot 2.78 / 0.96$ & 6.00 & 5.64 & 6.32 & 0.334 & 0.314 \\
\hline & $1000 \mathrm{Ix}$ & 4. $73 Y R \cdot 2.15 / 1.11$ & 3.73 & 3.53 & 3.34 & 0.352 & 0.333 \\
\hline & $500 \mathrm{Ix}$ & $0.37 Y \cdot 1.28 / 1.29$ & 1.72 & 1.64 & 1.16 & 0.381 & 0.363 \\
\hline & $2001 x$ & & 2 & 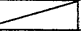 & & 7 & 7 \\
\hline \multirow{4}{*}{$\begin{array}{l}\text { N } 5000 \\
\text { Gray }\end{array}$} & $1500 \mathrm{Ix}$ & $5.45 \mathrm{RP} \cdot 6.67 / 3.19$ & 41.41 & 38.40 & 45.68 & 0.330 & 0.306 \\
\hline & $1000 \mathrm{Ix}$ & $5.22 \mathrm{R} \cdot 5.60 / 2.37$ & 27.36 & 25.60 & 27.04 & 0.342 & 0.320 \\
\hline & $5001 x$ & 8. $79 \mathrm{YR}=4.00 / 2.07$ & 12.40 & 12.00 & 9.30 & 0.368 & 0.356 \\
\hline & $2001 x$ & $0.74 R P \cdot 3.05 / 1.41$ & 7.36 & 6.78 & 9.08 & 0.317 & 0.292 \\
\hline \multirow{4}{*}{$\begin{array}{l}\text { N } 8000 \\
\text { White }\end{array}$} & $1500 \mathrm{Ix}$ & $7.50 \mathrm{YR} \cdot 10.0 / 1.00$ & 152.82 & 151.00 & 151.00 & 0.336 & 0.332 \\
\hline & $1000 \mathrm{Ix}$ & $7.31 \mathrm{YR} \cdot 9.88 / 0.33$ & 100.55 & 99.40 & 88.16 & 0.349 & 0.345 \\
\hline & $5001 x$ & $1.60 Y \cdot 7.21 / 4.39$ & 46.20 & 46.20 & 28.86 & 0.381 & 0.381 \\
\hline & $200 \mathrm{Ix}$ & $4.41 \mathrm{R} \cdot 5.24 / 0.66$ & 22.14 & 22.00 & 25.26 & 0.319 & 0.317 \\
\hline
\end{tabular}

Table 5 Comparison of $\mathrm{Y}$ value between longitudinal surface and cross-sectional surface of pompon

\begin{tabular}{|c|c|c|c|}
\hline & Y value & longitudinal surface of pompon & Cross-sectional surface of pompon * \\
\hline$R$ & 288070 & 11.68 & 13.61 \\
\hline $\mathbf{G}$ & 767030 & 26.79 & 26.95 \\
\hline $\mathrm{B}$ & 648050 & 24.84 & 28.35 \\
\hline $\mathrm{N}$ & $0000 \mathrm{BIack}$ & 2. 44 & 2. 59 \\
\hline $\mathrm{N}$ & 5000 Gray & 18.65 & 18.80 \\
\hline $\mathrm{N}$ & 8000 White & 46.10 & 72.80 \\
\hline
\end{tabular}

ン糸側面集合体の色に近いことがわかる.

また，糸側面集合体の $\mathrm{Y}$ 值を 2 倍にした值は, ボ ンテンの表面照度を1500 1x にして, 非接触で测色 した Y 值とほぼ一致することがわかった。 例えば, 表 5 のボンテン番号 N5000 Gray の糸側面集合体の $\mathrm{Y}$ 值 : 18.65の 2 倍の值は, 表 4 の1500 lx で, 非接 触で測色した $\mathrm{Y}$ 值：38.40に近い值となる。つま り, 我々が普通1500 lx の明るさで, カーペットを見 ているすのと同じ色のカーペットの色だしをする場 合, カーペット糸の色の Y 值を $1 / 2$ に下げた值に 色だしをすればよいことになる。

但し, White だけ, 非接触で測色したボンテンの $\mathrm{Y}$ 值が大きな值を示しているのは, 相互反射が大き いためと考えられる.この点については, さらに検 討を加えてみたい.

\section{3 ボンテン内部の照度}

表 6 にボンテン内部の深さが変化した場合の照度
測定結果を示す. 図 4 にボンテン内部の深さと照度 の関係をグラフにしたものを示す. 表 6 と図 4 から ボンテン内部の照度は, 表面からの深さが下がるほ ど照度も低下することがわかる. ボンテンの表面 1500 lx から 5mm 下がった深さの照度は, 400 lx〜 750 lx，特に色相や彩度に左右されない Gray は, $459.151 \mathrm{x}$ となり，69.4\%の照度低下率となる．ま た，表面から $10 \mathrm{~mm}$ 下がった深さの照度は，150 lx 以下の照度を示すことがわかった．このとき, Gray は $44.25 \mathrm{~lx}$ となり, $97.1 \%$ 照度低下率を示してい る。つまりボンテン内照度は, 表面から $5 \mathrm{~mm}$ 下が ると $50 \%$ 以上低下し，10mm 下がると $90 \%$ 以上低下 することがわかった。

図 5 に 2 本のカーペット糸間を拡大し, モデル化 した「ボンテン・モデル」を示し，入射角と反射角の 位置関係を示す. また, 表 7 にボンテンの樑さ $d$ を $10 \mathrm{~mm}$, ボンテン糸開き幅 $W$ を $0.5 \mathrm{~mm} \sim 2.0 \mathrm{~mm}$, 最初の入射・反射角 $\theta_{1}$ を垂直入射 $\left(90^{\circ}-\alpha / 2\right)$, 
Table 6 Illuminance variation according to depth from surface of pompon

\begin{tabular}{|c|c|c|}
\hline Sample & $5 \mathrm{~mm}$ under from surface (lx) & $10 \mathrm{~mm}$ under from surface $(\mathrm{lx})$ \\
\hline $\mathrm{R} 2288070$ & $731.40 \quad[51.2 \%]$ & $128.70 \quad\left[\begin{array}{lll}9 & 1.4 \%]\end{array}\right.$ \\
\hline 767030 & $\begin{array}{llll}744.45 & {[50.4 \%]}\end{array}$ & $147.75 \quad[90.2 \%]$ \\
\hline B 648050 & $572.70 \quad\left[\begin{array}{llll}6 & 1 . & 9 \%\end{array}\right]$ & $45.00 \quad[97.0 \%]$ \\
\hline $\mathrm{N} 0000 \mathrm{~B} \mathrm{lack}$ & $405.75 \quad\left[\begin{array}{lll}73 . & 0 \%\end{array}\right]$ & $51.75 \quad[96.6 \%]$ \\
\hline $\mathrm{N} 550000$ G ra & \begin{tabular}{|llll}
459. & 15 & {$[69.4 \%]$} \\
\end{tabular} & $44.25 \quad[97.1 \%]$ \\
\hline $\mathrm{N} 8000$ Wh i t e & $730.50 \quad[51.3 \%]$ & $119.55 \quad\left[\begin{array}{lll}9 & 2 . & 0 \%\end{array}\right]$ \\
\hline
\end{tabular}

Surface of pompon : $1500 \mathrm{~lx}$

[ ] is illuminance reduction rate.

Table 7 Relationship between reflection angle and reflection depth of light inside pompon

\begin{tabular}{|c|c|c|c|c|c|c|c|c|c|c|c|}
\hline Incidence angle & $\begin{array}{l}\text { Depth of } \\
\text { pompom (mm) }\end{array}$ & $\begin{array}{l}\begin{array}{l}\text { Open width of } \\
\text { yarn }(\mathrm{mm})\end{array} \\
\end{array}$ & $\begin{array}{l}\text { Open angle of } \\
\text { yarn } \alpha\left(^{\circ}\right)\end{array}$ & $\begin{array}{l}\text { Open angle of } \\
\text { visual point } \beta\left(^{\circ}\right)\end{array}$ & $\theta 1$ & $\overline{\theta 2}$ & $\theta 3$ & $\theta 4$ & $\theta 5$ & $\overline{\theta 6}$ & $\overline{\theta 7}$ \\
\hline \multirow{4}{*}{$90^{\circ}-\alpha / 2$} & 10.00 & 0.50 & 2.87 & 0.00 & $\begin{array}{c}88.57 \\
\mathrm{~d} 1=6.53 \\
\end{array}$ & $\begin{array}{r}85.70 \\
d 2=7.81 \\
\end{array}$ & $\begin{array}{r}82.84 \\
\mathrm{~d} 3=8.36\end{array}$ & $\begin{array}{r}79.97 \\
d 4=8.66 \\
d\end{array}$ & $\begin{array}{r}77.10 \\
\mathrm{~d} 5=8.85\end{array}$ & $\begin{array}{r}74.24 \\
d 6=8.98 \\
\end{array}$ & $\begin{array}{r}71.37 \\
d 7=9.07\end{array}$ \\
\hline & 10.00 & 1.00 & 5.73 & 0.00 & $\begin{array}{c}87.14 \\
d 1=6.59 \\
\end{array}$ & $\begin{array}{c}81.41 \\
\mathrm{~d} 2=7.89 \\
\end{array}$ & $\begin{array}{r}75.68 \\
\mathrm{~d} 3=8.44 \\
\end{array}$ & $\begin{array}{c}69.95 \\
d 4=8.74 \\
\end{array}$ & $\begin{array}{c}64.23 \\
\mathrm{~d} 5=8.93 \\
\end{array}$ & $\begin{array}{r}58.50 \\
d 6=9.05 \\
\end{array}$ & $\begin{array}{r}52.77 \\
\mathrm{~d} 7=9.14 \\
\end{array}$ \\
\hline & 10.00 & 1.50 & 8.58 & 0.00 & $\begin{array}{c}85.71 \\
d 1=6.60 \\
\end{array}$ & $\begin{array}{r}77.13 \\
\mathrm{~d} 2=7.89 \\
\end{array}$ & $\begin{array}{r}68.54 \\
\mathrm{~d} 3=8.44 \\
\end{array}$ & $\begin{array}{c}59.96 \\
d 4=8.73 \\
\end{array}$ & $\begin{array}{r}51.38 \\
\mathrm{~d} 5=8.90 \\
\end{array}$ & $\begin{array}{r}42.80 \\
d 6=9.02 \\
\end{array}$ & $\begin{array}{r}54.21 \\
\mathrm{~d} 7=9.09 \\
\end{array}$ \\
\hline & 10.00 & 2.00 & 11.43 & 0.00 & $\begin{array}{c}84.29 \\
\mathrm{~d} 1=6.61 \\
\end{array}$ & $\begin{array}{r}72.86 \\
\mathrm{~d} 2=7.90\end{array}$ & $\begin{array}{r}61.43 \\
\mathrm{~d} 3=8.50\end{array}$ & $\begin{array}{c}50.01 \\
d 4=8.67 \\
\end{array}$ & $\begin{array}{c}38.58 \\
d 5=8.93\end{array}$ & $\begin{array}{r}27.15 \\
d 6=9.02\end{array}$ & $\begin{array}{r}15.72 \\
d 7=9.06\end{array}$ \\
\hline \multirow{4}{*}{$45^{\circ}$} & 10.00 & 0.50 & 2.87 & 87.13 & $\begin{array}{r}45.00 \\
d 1=0.46 \\
\end{array}$ & $\begin{array}{r}42.13 \\
\mathrm{~d} 2=0.86 \\
\end{array}$ & $\begin{array}{r}39.27 \\
\mathrm{~d} 3=1.21\end{array}$ & $\begin{array}{c}36.40 \\
\mathrm{~d} 4=1.51\end{array}$ & $\begin{array}{c}33.54 \\
\mathrm{~d} 5=1.77 \\
\end{array}$ & $\begin{array}{r}30.67 \\
d 6=2.00 \\
\end{array}$ & $\begin{array}{r}27.81 \\
d 7=2.19 \\
\end{array}$ \\
\hline & 10.00 & 1.00 & 5.73 & 84.27 & $\begin{array}{c}45.00 \\
\mathrm{~d} 1=0.86\end{array}$ & $\begin{array}{c}39.27 \\
\mathrm{~d} 2=1.51\end{array}$ & $\begin{array}{c}33.54 \\
d 3=2.00\end{array}$ & $\begin{array}{c}27.82 \\
d 4=2.36\end{array}$ & $\begin{array}{c}22.09 \\
d 5=2.62\end{array}$ & $\begin{array}{r}16.36 \\
d 6=2.80\end{array}$ & $\begin{array}{r}10.63 \\
d 7=2.89\end{array}$ \\
\hline & 10.00 & 1.50 & 8.58 & 81.42 & $\begin{array}{r}45.00 \\
d 1=1.21 \\
\end{array}$ & $\begin{array}{r}36.42 \\
\mathrm{~d} 2=2.00 \\
\end{array}$ & $\begin{array}{r}27.83 \\
d 3=2.50 \\
\end{array}$ & $\begin{array}{r}19.25 \\
\mathrm{~d} 4=2.80 \\
\end{array}$ & $\begin{array}{r}10.67 \\
d 5=2.92 \\
\end{array}$ & $\begin{array}{r}2.09 \\
d 6=2.88\end{array}$ & $\begin{array}{r}-6.50 \\
d 7=2.67\end{array}$ \\
\hline & 10.00 & 2.00 & 11.43 & 78.57 & $\begin{array}{r}45.00 \\
\mathrm{~d} 1=1.51 \\
\end{array}$ & $\begin{array}{r}33.57 \\
\mathrm{~d} 2=2.36 \\
\end{array}$ & $\begin{array}{r}22.15 \\
\mathrm{~d} 3=2.80\end{array}$ & $\begin{array}{c}10.72 \\
\mathrm{~d} 4=2.92 \\
\end{array}$ & $\begin{array}{c}-0.71 \\
d 5=2.76\end{array}$ & $\begin{array}{r}-12.13 \\
d 6=2.28\end{array}$ & $\begin{array}{r}-23.56 \\
d 7=1.37 \\
\end{array}$ \\
\hline \multirow{4}{*}{$60^{\circ}$} & 10.00 & 2.50 & 2.87 & 57.13 & $\begin{array}{c}60.00 \\
\mathrm{~d} 1=0.78 \\
\end{array}$ & $\begin{array}{r}57.13 \\
\mathrm{~d} 2=1.43 \\
\end{array}$ & $\begin{array}{r}54.27 \\
\mathrm{~d} 3=1.98 \\
\end{array}$ & $\begin{array}{r}51.40 \\
d 4=2.44 \\
\end{array}$ & $\begin{array}{c}48.54 \\
\mathrm{~d} 5=2.83 \\
\end{array}$ & $\begin{array}{r}45.67 \\
d 6=3.16 \\
\end{array}$ & $\begin{array}{r}42.81 \\
\mathrm{~d} 7=3.45 \\
\end{array}$ \\
\hline & 10.00 & 3.00 & 5.73 & 54.27 & $\begin{array}{r}60.00 \\
\mathrm{~d} 1=1.43 \\
\end{array}$ & $\begin{array}{r}54.27 \\
\mathrm{~d} 2=2.44 \\
\end{array}$ & $\begin{array}{c}48.54 \\
\mathrm{~d} 3=3.17\end{array}$ & $\begin{array}{c}42.82 \\
d 4=3.72\end{array}$ & $\begin{array}{r}37.09 \\
d 5=4.12\end{array}$ & \begin{tabular}{|r|}
31.36 \\
$\mathrm{~d} 6=4.43$ \\
\end{tabular} & $\begin{array}{r}25.63 \\
d 7=4.66 \\
\end{array}$ \\
\hline & 10.00 & 3.50 & 8.58 & 51.42 & $\begin{array}{r}60.00 \\
\mathrm{~d} 1=1.98 \\
\end{array}$ & $\begin{array}{r}51.42 \\
\mathrm{~d} 2=3.17 \\
\end{array}$ & $\begin{array}{c}42.83 \\
\mathrm{~d} 3=3.94 \\
\end{array}$ & $\begin{array}{c}34.25 \\
\mathrm{~d} 4=4.44 \\
\end{array}$ & $\begin{array}{r}25.67 \\
d 5=4.75 \\
\end{array}$ & $\begin{array}{r}17.09 \\
d 6=4.92 \\
\end{array}$ & $\begin{array}{r}8.51 \\
\mathrm{~d} 7=4.98 \\
\end{array}$ \\
\hline & 10.00 & 4.00 & 11.43 & 48.57 & $\begin{array}{r}60.00 \\
\mathrm{~d} 1=2.44 \\
\end{array}$ & $\begin{array}{c}48.57 \\
\mathrm{~d} 2=3.72 \\
\end{array}$ & $\begin{array}{r}37.15 \\
\mathrm{~d} 3=4.44\end{array}$ & $\begin{array}{c}25.72 \\
\mathrm{~d} 4=4.82 \\
\end{array}$ & $\begin{array}{r}14.29 \\
d 5=4.98 \\
\end{array}$ & $\begin{array}{r}2.87 \\
d 6=4.93 \\
\end{array}$ & $\begin{array}{r}-8.56 \\
d 7=4.66 \\
\end{array}$ \\
\hline
\end{tabular}

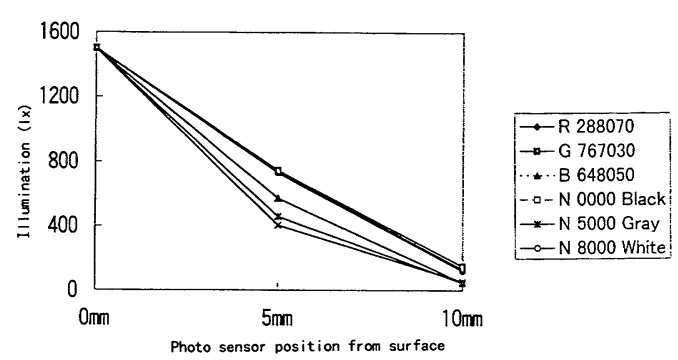

Fig. 4 Relationship between depth from surface of pompon and illuminance

$45^{\circ}, 60^{\circ}$ ，にしたときの $\theta_{2} \sim \theta_{7}$ の入射・反射角を示 す. マイナスの值は, ボンテンの表面に向かって逆 方向への反射を示す.このときの正反射深さ（ボン テン表面 $\mathrm{X}-\mathrm{X}^{\prime}$ からの距離）を $d_{1} \sim d_{7}$ とする.

表 7 から, 入射角 $\theta_{1}$ を垂直入射 $\left(90^{\circ}-\alpha / 2\right)$ とし た場合は，ボンテン糸開き幅 $W$ に関係なく， $\theta_{1}$ の 反射深さ $d_{1}$ で約 $6.5 \mathrm{~mm}$ 近くまでゆき, $\theta_{7}$ の反射深 さ $d_{7}$ で $9 \mathrm{~mm}$ まで光が進入する.

入射角 $\theta_{1}$ が $45^{\circ}$ の場合は, ボンテン糸開き幅 $W$ が小さければ, ボンテン糸間幅 $W$ が，大きくなる と反射深さ $d_{5}$ が $3 \mathrm{~mm}$ に到達する前に光がボンテ

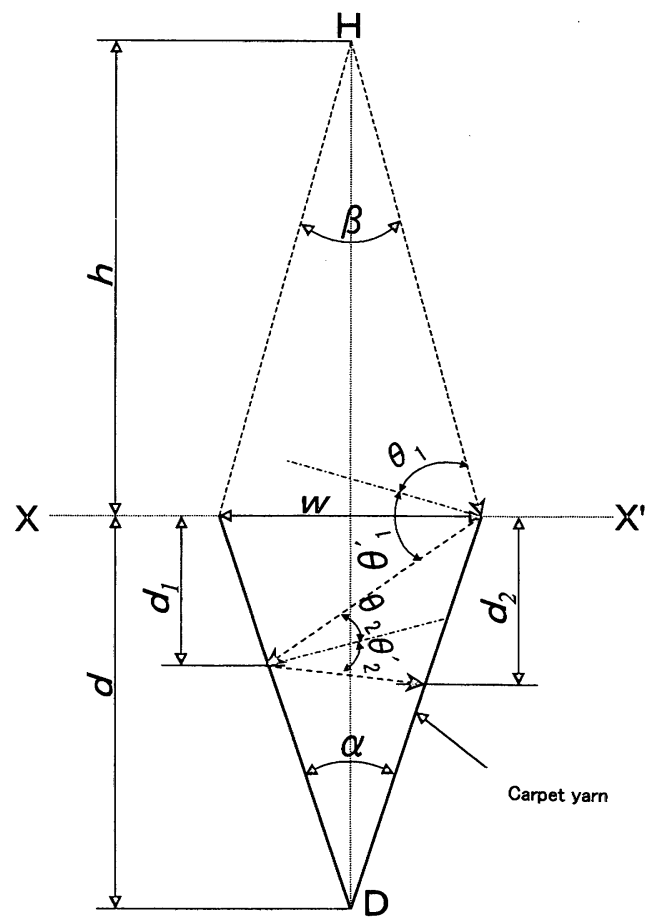

Fig. 5 Pompon model (magnification of area between two yarns) 
Table 8 Reflection rate of light as a function of incidence-receiving angle

\begin{tabular}{|c|c|c|c|c|c|c|}
\hline Sample & $30^{\circ}-30^{\circ}$ & $40^{\circ}-40^{\circ}$ & $45^{\circ}-45^{\circ}$ & $50^{\circ}-50^{\circ}$ & $60^{\circ}-60^{\circ}$ & $70^{\circ}-70^{\circ}$ \\
\hline N0000 Black & 4. $5(x)$ & 5. $6(\%)$ & 6. $3(\%)$ & 7. $6(x)$ & $11.5(\%)$ & 15. 1(x) \\
\hline N5000 Gray & $28.5(\%)$ & $34.0(\%)$ & $36.1(x)$ & $40.0(x)$ & $47.0(\%)$ & 54.3(\%) \\
\hline N 8000 White & $57.7(x)$ & $66.0(\%)$ & $70.1(x)$ & $72.0(\%)$ & $75.8(\%)$ & $78.3(\%)$ \\
\hline White Reflectance Standard & $100.0(\%)$ & $100.0(\%)$ & $100.0(x)$ & $100.0(\%)$ & $100.0(\%)$ & $100.0(\%)$ \\
\hline
\end{tabular}

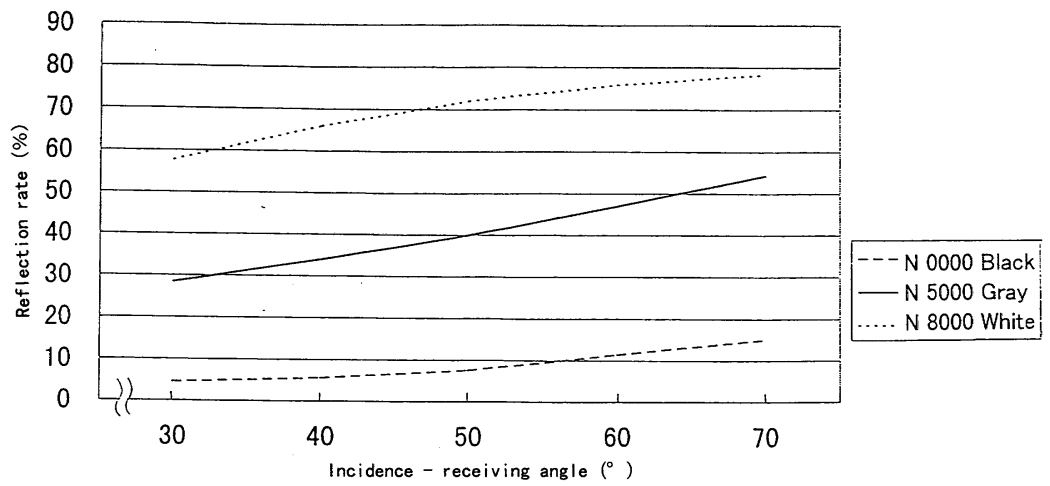

Fig. 6 Influence of incidence-receiving angle on reflection rate of light

ンの表面に向かって逆方向に反射する.

入射角 $\theta_{1}$ が $60^{\circ}$ の場合は，反射深さ $d_{n}$ が $45^{\circ}$ のと きよりあ大きくなっている. 同様に, ボンテン糸間 幅 $W$ が大きくなるにつれて, ボンテン内での反射 深さ $d_{n}$ は大きくなる.

入射・反射角が小さければ，ボンテン内での反射 深さ $d_{n}$ は，ボンテン糸開き幅 $W$ が大きく影響す る. ボンテン糸開き幅 $W$ が小さければボンテン内 での反射深さ $d_{n}$ あ小さく, ボンテン糸開き幅 $W$ が 大きければボンテン内での反射深さ $d_{n}$ あ大きくな る.

入射・反射角が大きければ，ボンテン糸開き幅 $W$ にボンテンの反射深さ $d_{n}$ はあまり影響されず, ボンテン内部へと光が進入することがわかる.
次に, 表 8 にゴニオフォトメータにより測定した ニュートラル色 (白, 灰, 黒) 3 種類のボンテンにつ いて, 入射・受光角を各々 $30^{\circ}, 40^{\circ}, 45^{\circ}, 50^{\circ}, 60^{\circ}$, $70^{\circ}$ としたきの光反射率の関係を示す. また, これら の測定結果を図 6 に示す. 表 9 にボンテン糸開き幅 $W: 1.0 \mathrm{~mm}$ のときのボンテン内光反射角 $\theta_{1} \sim \theta_{7}$ の それぞれの角度, 反射深さとその角度における反射 率を示す。

ボンテン内の光の反射条件については, 図 5 に示 すボンテン内の 2 本のカーペット糸間を拡大し，モ デル化した「ボンテン・モデル」を用いて以下のよ うに計算を行った。

$\mathrm{X}-\mathrm{X}^{\prime}$ は, ボンテンの表面位置を示し, $\alpha$ はボンテ ン内の糸と糸の開き角を示す.

Table 9 Relationship between reflection angle reflection depth from surface and reflection rate of light inside pompon

\begin{tabular}{|c|c|c|c|c|c|c|c|}
\hline & $\begin{array}{l}\theta 1=45^{\circ} \\
\text { d } 1=0.86\end{array}$ & $\begin{array}{l}\theta \quad 2=39.27^{\circ} \\
\text { d } 2=1.51\end{array}$ & $\begin{array}{l}\theta 3=33.54^{\circ} \\
\text { d } 3=2.00\end{array}$ & $\begin{array}{l}\theta 4=27.82^{\circ} \\
\text { d } 4=2.36\end{array}$ & $\begin{array}{l}\theta 5=22.09^{\circ} \\
\text { d } 5=2.62\end{array}$ & $\begin{array}{l}\theta 6=16.36^{\circ} \\
\text { d } 6=2.80\end{array}$ & $\begin{aligned} \theta 7 & =10.63^{\circ} \\
\text { d } 7 & =2.89\end{aligned}$ \\
\hline N0000 Black & $6.0 \%$ & $0.3 \%$ & & $4=2.00$ & 0 & 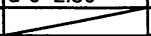 & \\
\hline N5000 Gray & $36.0 \%$ & $11.7 \%$ & $3.5 \%$ & $1.0 \%$ & 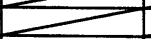 & 2 & 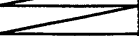 \\
\hline N8000 White & $70.0 \%$ & $45.6 \%$ & $27.8 \%$ & $15.3 \%$ & $7.2 \%$ & $2.7 \%$ & $0.7 \%$ \\
\hline & $\theta 1=60^{\circ}$ & $\theta 2=54.27^{\circ}$ & $\theta 3=48.54^{\circ}$ & $\theta 4=42.82^{\circ}$ & $\theta 5=37.09^{\circ}$ & $\theta 6=31.36^{\circ}$ & $\theta 7=25.63^{\circ}$ \\
\hline & $\mathrm{d} 1=1.43$ & d 2 $=2.44$ & d 3 $=3.17$ & d $4=3.72$ & $d 5=4.12$ & d $6=4.43$ & d $7=4.66$ \\
\hline N0000 Black & $11.5 \%$ & $1.0 \%$ & $0.1 \%$ & & - & 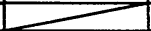 & 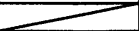 \\
\hline N5000 Gray & $47.0 \%$ & $20.2 \%$ & $7.9 \%$ & $2.8 \%$ & $0.9 \%$ & $0.3 \%$ & $0.1 \%$ \\
\hline N8000 White & $75.8 \%$ & $56.1 \%$ & $39.8 \%$ & $27.1 \%$ & $17.1 \%$ & $9.7 \%$ & $5.1 \%$ \\
\hline & $\theta 1=87.14^{\circ}$ & $\theta 2=81.41^{\circ}$ & $\theta 3=75.68^{\circ}$ & $\theta 4=69.95^{\circ}$ & $\theta 5=64.23^{\circ}$ & $\theta 6=58.50^{\circ}$ & $\theta 7=52.77^{\circ}$ \\
\hline & d $1=6.59$ & d 2 $=7.89$ & d $3=8.44$ & d $4=8.74$ & $d 5=8.93$ & d $6=9.05$ & d $7=9.14$ \\
\hline NO000 Black & $19.5 \%$ & $3.6 \%$ & $0.6 \%$ & $0.1 \%$ & & & 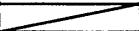 \\
\hline N5000 Gray & $67.0 \%$ & $41.5 \%$ & $24.1 \%$ & $13.0 \%$ & $6.5 \%$ & $3.0 \%$ & $1.3 \%$ \\
\hline N8000 White & $83.0 \%$ & $67.6 \%$ & $54.5 \%$ & $43.0 \%$ & $33.3 \%$ & $25.2 \%$ & $18.4 \%$ \\
\hline
\end{tabular}


光源とボンテンとの位置関係は, 光源の高さを $h$, ボンテンの深さを $d$, ボンテン糸開き幅を $W$ と する. 図 5 に示す角 $\alpha, \beta$ は, 次の式で求めることが できる。

$$
\begin{aligned}
& \alpha=2 \tan ^{-1}(W / 2 d) \\
& \beta=2 \tan ^{-1}(W / 2 h)
\end{aligned}
$$

実験值と比較するためボンテンの深さ $d$ を $10 \mathrm{~mm}$ として，ボンテン糸開き幅 $W$ を $0.50 \mathrm{~mm} \sim 2.75 \mathrm{~mm}$ と変化させると, $\alpha$ は $2.87^{\circ} \sim 15.67^{\circ}$ となる.

図 5 から入射角之反射角の位置関係は，入射角を $\theta_{1}, \theta_{2}, \theta_{3}, \cdots \cdots \theta_{\mathrm{n}}$ (n: 正整数), 反射角 $\theta_{1}^{\prime}, \theta_{2}^{\prime}, \theta_{3}^{\prime}$, $\cdots \cdots \cdot \theta_{\mathrm{n}}^{\prime}$ (n: 正整数) とすると, $\theta_{1} \sim \theta_{\mathrm{n}}$ は反射の法則 から $\theta=\theta^{\prime}$ となり,

$$
\begin{aligned}
& \theta_{1}=\left(180^{\circ}-\alpha-\beta\right) / 2 \\
& \theta_{2}=\left(180^{\circ}-3 \alpha-\beta\right) / 2 \\
& \theta_{\mathrm{n}}=\left\{180^{\circ}-(2 \mathrm{n}-1) \alpha-\beta\right\} / 2
\end{aligned}
$$

となる。

何回反射するかは，(1) 式で, $\theta_{\mathrm{n}}<0$ となる $\mathrm{n}$ から 求められる. すなわち, $\mathrm{n}$ が

$$
\mathrm{n}>\left(180^{\circ}-\beta+\alpha\right) / 2 \alpha
$$

のとき, 光は表面に向かってもどってくる. ここで は, 7 回 $(\mathrm{n}=7)$ までの正反射角 $\theta_{1} \sim \theta_{7}$ を求める.

ボンテン表面 $\left(\mathrm{X}-\mathrm{X}^{\prime}\right)$ からの反射深さを $d_{1}, d_{2}$, $\cdots \cdots d_{n}$ 之する. $d_{n}$ は下記の式で求められた。

図 7 の入射角之反射角の位置関係 (拡大図) にお いて, $\mathrm{D}$ は光の反射位置, $\mathrm{d}$ は光の反射位置の深さ を示す.

$$
\begin{aligned}
& \mathrm{D}_{\mathrm{n}}^{\prime} \mathrm{M}_{\mathrm{n}}=\chi_{\mathrm{n}} \text { とすると, } \Delta \mathrm{D}_{\mathrm{n}}^{\prime} \mathrm{M}_{\mathrm{n}} \mathrm{D}_{\mathrm{n}+1} \text { より, } \\
& \mathrm{M}_{\mathrm{n}} \mathrm{D}_{\mathrm{n}+1}=\chi_{\mathrm{n}} \cdot \tan \left(90^{\circ}-\alpha / 2\right)
\end{aligned}
$$

であり, $\Delta \mathrm{D}_{\mathrm{n}} \mathrm{M}_{\mathrm{n}} \mathrm{D}_{\mathrm{n}+1}$ より

$$
\mathrm{M}_{\mathrm{n}} \mathrm{D}_{\mathrm{n}+1}=\left(W-2 \Sigma \chi_{\mathrm{i}}-\chi_{\mathrm{n}}\right) \cdot \tan \left(\theta_{\mathrm{n}}-\alpha / 2\right)
$$

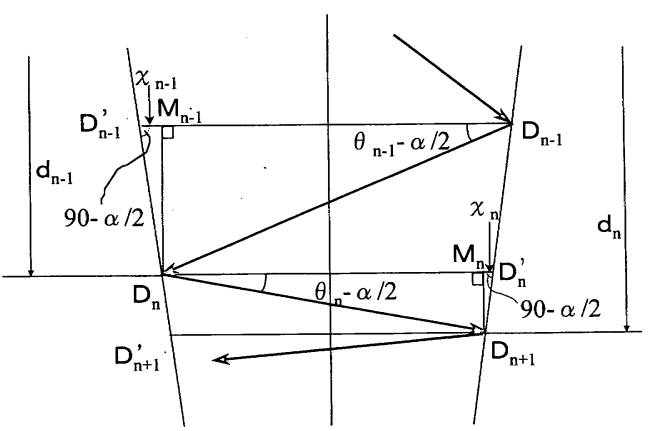

Fig. 7 Relationship between incidence angle and receiving angle (Magnification)
である.一方

$\Sigma \chi_{\mathrm{i}}=\Sigma\left(d_{\mathrm{n}}-d_{\mathrm{n}-1}\right) \cdot \tan (\alpha / 2)=d_{\mathrm{n}-1} \cdot \tan (\alpha /$

2) となる. したがって， $\chi_{\mathrm{n}}$ および $d_{\mathrm{n}}$ は，以下のよ

うになる。

$$
\begin{aligned}
& \chi_{\mathrm{n}}=\frac{\left(W-2 d_{\mathrm{n}-1} \cdot \tan (\alpha / 2)\right) \cdot \tan \left(\theta_{\mathrm{n}}-\alpha / 2\right)}{\tan \left(90^{\circ}-\alpha / 2\right)+\tan \left(\theta_{\mathrm{n}}-\alpha / 2\right)} \\
& d_{\mathrm{n}}=\frac{\left(W-2 d_{\mathrm{n}-1} \cdot \tan (\alpha / 2)\right) \cdot \tan \left(\theta_{\mathrm{n}}-\alpha / 2\right) \cdot \tan \left(90^{\circ}-\alpha / 2\right)}{\tan \left(90^{\circ}-\alpha / 2\right)+\tan \left(\theta_{\mathrm{n}}-\alpha / 2\right)}+d_{\mathrm{n}-1}
\end{aligned}
$$

但し， $d_{0}=0$ とする.

また同様の方法で，ボンテンの真上から光が垂直 入射した場合の入射角を $\left(90^{\circ}-\alpha / 2\right)$ とし，入射角 $\theta_{1} \sim \theta_{\mathrm{n}}$ およびそのときのボンテン表面からの深さ $d$ ${ }_{1} \sim d_{\mathrm{n}}$ を求める.

次に表 7 に示すボンテン内での光反射角のよう に,「ボンテン・モデル」内を光が角度を変化させて 入射一射を繰り返すと考えられる。そそのため， 3 種 類のボンテンのカーペット糸を平行に並べ, 系に対 して平行に光を入射したときの入射・反射角が $30^{\circ}$, $40^{\circ}, 45^{\circ}, 60^{\circ}$ のときの正反射光量をゴニオフォトメ 一タ ${ }^{5)}$ (村上色彩研究所製 GP-IR 型) で測定し,「ボ ンテン・モデル」内のそれぞれの入射角に代入して 反射率を求めた。このとき，それぞれの角度におけ る標準白板の正反射率を $100 \%$ とした．また，この反 射率をグラフに描き, 上記以外の角度については, グラフから反射率を求めた.

計算式（1)，(2) から求めたボンテン内の光反射 角 $\theta_{1} \sim \theta_{7}$ のボンテン糸開き幅 $\mathrm{W}=1.0 \mathrm{~mm}$ とし, 求 めた反射率を代入して, 光の反射・吸収量からボン テン内部の光反射特性を検討した. ボンテン糸開き 幅 $W$ は，糸密度によっても変化するので，ここで は実際のカーペットを想定して $W$ を $1.0 \mathrm{~mm}$ とし て検討した。

表 9 よりボンテンの真上から光を垂直入射させた 場合を除いて，ボンテン表面から $5 \mathrm{~mm}$ 下がった深 さでは光が到達する以前に，ほとんどの光は反射吸 収される. 特に Black は, 2〜3 回の反射で光はほと んど吸収される.ボンテンの真上から光を垂直入射 した場合は, 表面から約 $9 \mathrm{~mm}$ 下がった深さまで, 光が反射しながらボンテン内を進む. このとき, ボ ンテン表面から $6.59 \mathrm{~mm}$ 下がった深さで, 計算か ら, Black: 19.5\%, Gray:67.0\%, White: 83.0\%の反射率となる.

光が垂直入射 $\left(90^{\circ}-\alpha / 2\right), 45^{\circ}, 60^{\circ}$ で入射した場 合の入射光量の寄与率は $45 \%, 32 \%, 23 \%$ と求めら 
れる. 但し，このときの入射光量全体を $100 \%$ とす る. 入射光量の寄与率は, 例えば，真上から光が入 射した場合, 次のように求めた. $\cos 0^{\circ} /\left(\cos 0^{\circ}+\right.$ $\left.\cos 45^{\circ}+\cos 60^{\circ}\right)$ ᄂ 0.45 となり寄与率を $45 \%$ とし た. $45^{\circ}, 60^{\circ}$ も同様に求めた. 次に表 9 に示した計 算値から求めたボンテンの表面から6.59mm 下が った深さの光反射率に，垂直入射 $\left(90^{\circ}-\alpha / 2\right)$ の寄 与率 $45 \%$ を乗ずると，Black の光吸収率は，91.2\% となり，明るさは132 1x となる，同様に Gray は, 光 吸収率 $69.9 \%$ で, 明るさは, $4521 \mathrm{x}$, White は, 光吸 収率62.6\%で明るさは561 1x となる。

また, 表面から9.14 mm下がった深さでは, Black は, 光が吸収されてしまう. Gray は，反射率 $1.3 \%$, White は, $18.4 \%$ となるが, ポンテンの表面 から6.59mm 下がった深さの光反射率と同様，入射 光量の寄与率 $45 \%$ を乗ずると, Gray の光吸収率は, $99.4 \%$ となり, 明るさは $9 \mathrm{~lx}$ とわずかである. White は, 光吸収率が $91.72 \%$ となり，明るさは $124.21 \mathrm{x}$ となる。

計算値と実測值の誤差は, 計算値を単一光として 入射光寄与率という方法で検討したことによると考 えられる. Black は，ほぼ光が吸収され，Whiteで あ80\%吸収されてしまうことになる. 実際に光は, 垂直入射 $\left(90^{\circ}-\alpha / 2\right), 45^{\circ}, 60^{\circ}$ とその他の角度加ら 光が入射し, 反射を繰り返している. また, 糸開き 幅 $W$ すランダムな組み合わせであり，その反射位 置の樑さは, 表 7 のように変化する. 今回, 計算上 では, White, Gray, Blackのニュートラル色につ いてのみ検討したが，カーペットの色によっても， 様々に変化すると考えられる. 入射角度, 入射位置, 糸開き幅，色などを考慮して，全体の入射光を考え れば，ボンテン表面から $5 \mathrm{~mm}$ 下がった深さの明る さは，実㳇値の様に約50\%吸収されたことになる。

\section{4. 結 論}

本研究において次のようなことがわかった。

1）カーペットの糸側面集合体の色よりあ, 糸断面集 合体の色が濃色なのは, 彩度よりあ明るさがカー ペットの色にかかわる.

2）我々がカーペットを見るときは, 系の断面だけで なく,糸と系の陰影など, トータルとしてカーペ
ットを見ている，つまりここの陰影および光吸収 がカーペットの色が糸側面集合体よりも，濃色に 見える要因として考えられる.

3）我々が実際にカーペットを見るように非接触で, ボンテン表面照度を750 1x で測色した場合， $\mathrm{Y}$ 値 は系側面集合体の明るさに相当することがわかっ た.

4）カーペットの内部の明るさを, ボンテン・モデル を用いて, 計算から照度変化を求めてみると, 光 の入射角が大きいほど，ボンテン内部へ光は進入 せず，表面から $5 \mathrm{~mm}$ の深さまでに，反射吸収さ れてしまう．真上から光を入射した場合が最もボ ンテン内部に光は進入する. それは，特にカーペ ット糸の Y 値が大きいるのほど顕著であること がわかった。

5）照度センサーを用いてボンテン内部の照度を測 定した場合，センサーの深さをボンテン表面から 下げるほど照度す低下し，5mm 下げると約 $50 \%$, $10 \mathrm{~mm}$ 下げると約 $90 \%$ 低下することがわかった. 実際に我々がカーペットを見る場合，光はあらゆ る角度から入射・反射を綝り返し，系の陰影および 光の吸収が行われている.これらが影響し合った状 態を我々はカーペットの色として知覚している，そ のため, 明るさ Y 值とカーペットの色は, 大きく関 係していることが確認された。

本研究は，日本織維機械学会第49回，第50回年次 大会研究発表会で発表した内容を主にまとめたもの である.

\section{参考文献}

1) Japan Carpet Association ; "Carpet Handbook" p. 64, Japan Carpet Association, (1992)

2) Isikawa, Yobiko, Nezu, Mishima, Sakai and Kato; Technology Research Institute of Osaka Prefecture Report 6 (1973)

3) T. Gunji, K Nihira and T. Tuboi ; J. Text. Mach. Soc. Japan (Japanese Ed), 24, T33 (1971)

4) Color Science Association of Japan ; "Sinpan Sikisai Kagaku Handbookn, University of Tokyo Press, (1980)

5) I. Maekawa, T. Gunji and T. Tuboi ; J. Text. Mach. Soc. Japan (Japanese Ed), 35, T117 (1982)

6) H. Hasunuma ; "Kotaku", Corona Publishing Co. LTD. (1961)

7) T. Uehara ; "Hikari to Shomei eno Sasoi", Nihon Riko Shuppankai, (1994) 